University of Nebraska - Lincoln

DigitalCommons@University of Nebraska - Lincoln

2012

\title{
United States Registered Nurse Workforce Report Card and Shortage Forecast
}

Stephen P. Juraschek

Johns Hopkins Medical Institutions, Baltimore, MD

Xiaoming Zhang

Cleveland Clinic, Cleveland, $\mathrm{OH}$

Vinoth K. Ranganathan

Cleveland Clinic, Cleveland, $\mathrm{OH}$

Vernon Lin

Louis Stokes Cleveland Veterans Affairs Medical Center, Cleveland,

Follow this and additional works at: https://digitalcommons.unl.edu/publichealthresources

Part of the Public Health Commons

Juraschek, Stephen P.; Zhang, Xiaoming; Ranganathan, Vinoth K.; and Lin, Vernon, "United States Registered Nurse Workforce Report Card and Shortage Forecast" (2012). Public Health Resources. 149. https://digitalcommons.unl.edu/publichealthresources/149

This Article is brought to you for free and open access by the Public Health Resources at DigitalCommons@University of Nebraska - Lincoln. It has been accepted for inclusion in Public Health Resources by an authorized administrator of DigitalCommons@University of Nebraska - Lincoln. 


\title{
United States Registered Nurse Workforce Report Card and Shortage Forecast
}

American Journal of Medical Quality 27(3) 24I-249

(C) 2012 by the American College of Medical Quality

Reprints and permission:

sagepub.com/journalsPermissions.nav DOI: $10.1|77 / 10628606|$ |4|6634

http://ajmq.sagepub.com

\author{
Stephen P. Juraschek, BA, ${ }^{1,2}$ Xiaoming Zhang, PhD, ${ }^{3}$ \\ Vinoth K. Ranganathan, MSE, MBA, ${ }^{3}$ and Vernon W. Lin, MD, PhD ${ }^{2,3}$
}

\begin{abstract}
Registered nurses (RNs) play a critical role in health care delivery. With an aging US population, health care demand is growing at an unprecedented pace. Using projected changes in population size and age, the authors developed demand and supply models to forecast the RN job shortage in each of the 50 states. Letter grades were assigned based on projected RN job shortage ratios. The number of states receiving a grade of "D" or "F" for their RN shortage ratio will increase from 5 in 2009 to 30 by 2030, for a total national deficit of 9 I8 232 (7256 I9 - I I I I I I) $\mathrm{RN}$ jobs. There will be significant RN workforce shortages throughout the country in 2030; the western region will have the largest shortage ratio of $389 \mathrm{RN}$ jobs per 100000 . Increased efforts to understand shortage dynamics are warranted.
\end{abstract}

\section{Keywords}

nursing workforce shortage, nursing job supply, shortage projection

Registered nurses (RNs) play an integral role in health care delivery. ${ }^{1-3}$ Increases in RN staffing proportions confer both personal benefit to patients and fiscal advantage to hospitals. ${ }^{4,5}$ Since 1998, the United States has experienced a growing $\mathrm{RN}$ deficit, ${ }^{6-8}$ primarily because of the growing elderly population ${ }^{7,9,10}$ and aging nurses. ${ }^{11}$ As a result, RN demand continues to outstrip RN supply, creating an unprecedented shortage of RNs in the United States.

Concern about RN shortages has led a number of researchers and government organizations to attempt to predict future RN supply and demand..$^{6,8,12,13}$ The models used incorporate workforce dynamics to forecast future nursing supply and demand and project that there will be a national shortage of 300000 to 1 million $\mathrm{RN}$ jobs in 2020. Unlike other projection models, the current study focuses specifically on the impact that population and age will have on the nursing workforce in relation to current staffing ratios. Furthermore, this article uses a published grading methodology to facilitate comparison between current and future regional $\mathrm{RN}$ staffing levels. The results of the current study provide points of discussion for the RN profession, policy makers, and stakeholders when evaluating current and future $\mathrm{RN}$ needs to mitigate predicted shortages.

\section{Methods}

Design and Sample

This article forecasts state $\mathrm{RN}$ job shortages by examining the difference between RN demand and RN supply in all 50 states (Table 1; definitions). Pursuant to this,

'Johns Hopkins Medical Institutions, Baltimore, MD

${ }^{2}$ Louis Stokes Cleveland Veterans Affairs Medical Center, Cleveland, $\mathrm{OH}$

${ }^{3}$ Cleveland Clinic, Cleveland, $\mathrm{OH}$

The authors declared no potential conflicts of interest with respect to the research, authorship, and/or publication of this article. The authors disclosed receipt of the following financial support for the research, authorship, and/or publication of this article: This study was supported in part by a grant from the California Institute for Nursing \& Health Care and the US Department of Veterans Affairs Rehabilitation Research and Development Service Merit Review Award. Mr Juraschek is funded by an NIH/NHLBI T32HL007024 Cardiovascular Epidemiology Training Grant.

\section{Corresponding Author:}

Vernon W. Lin, MD, PhD, Department of Physical Medicine and Rehabilitation, Cleveland Clinic, 9500 Euclid Avenue, S3I,

Cleveland, $\mathrm{OH} 44195$

Email: linv@ccf.org 
Table I. Explanation of Key Terms

\begin{tabular}{|c|c|}
\hline Key Terms & Definition \\
\hline $\begin{array}{l}\text { Bureau of Labor Statistics } \\
\text { (BLS) }\end{array}$ & $\begin{array}{l}\text { The official source of labor economic and statistical data for the federal government. Through } \\
\text { a semiannual survey, the BLS produces employment and wage estimates for } 800 \text { different } \\
\text { occupations on the national, state, and subregional levels (www.bls.gov). }\end{array}$ \\
\hline $\begin{array}{l}\text { Centers for Medicare \& } \\
\text { Medicaid Services (CMS) }\end{array}$ & Source of age-based personal health care expenditure estimates. ${ }^{17}$ \\
\hline $\begin{array}{l}\text { Current Population Survey } \\
\text { (CPS) }\end{array}$ & $\begin{array}{l}\text { CPS is a monthly survey of about } 50000 \text { households conducted by USCB and BLS. CPS is the } \\
\text { primary source of information on the labor force characteristics of the US population. }\end{array}$ \\
\hline $\begin{array}{l}\text { Full-time equivalent (FTE) } \\
\text { RNs }\end{array}$ & $\begin{array}{l}\text { FTE RNs are used as a means of measuring and reconciling the variation in workforce } \\
\text { participation among RNs by converting individuals who work full time or part time into a } \\
\text { single unit of measure. It does not represent the number of RN workers but the number of } \\
\text { full-time positions fulfilled by all existing workers in a workforce. A crude estimate of FTEs } \\
\text { may be calculated by multiplying estimated RN jobs by } 0.84 \mathrm{FTE} / \mathrm{RN} \text { jobs. }\end{array}$ \\
\hline $\begin{array}{l}\text { Health Resources and } \\
\text { Services Administration } \\
\text { (HRSA) }\end{array}$ & $\begin{array}{l}\text { HRSA is an agency of the US Department of Health and Human Services. It is the primary } \\
\text { federal agency collecting, analyzing, and disseminating health workforce information and } \\
\text { facilitating national, state, and local workforce planning efforts. }\end{array}$ \\
\hline Report card & $\begin{array}{l}\text { A collection of grades assigned to each state based on a grading rubric used for determining } \\
\text { stated (2009) or projected (2030) RN shortage ratios. }\end{array}$ \\
\hline National mean & $\begin{array}{l}844 \text { RN jobs per } 100000 \text { people. This value was based on the number of RNs in the United } \\
\text { States per } 100000 \text { people for } 2009 .^{21}\end{array}$ \\
\hline $\begin{array}{l}\text { Personal health care } \\
\text { expenditure (PHE) }\end{array}$ & $\begin{array}{l}\text { An estimate that takes into account "spending for hospital care, physician and clinical services, } \\
\text { dental care, other professional services, home health care, nursing home care, and health care } \\
\text { products purchased in retail outlets." This estimate does not include spending on public health } \\
\text { programs, health facility administration, health care research, and the construction of health } \\
\text { care facilities. }\end{array}$ \\
\hline Registered nurse (RN) & $\begin{array}{l}\text { An RN is a health care professional defined by BLS as responsible for implementing the practice } \\
\text { of nursing through the use of the nursing process in conjunction with other health care } \\
\text { professionals. RNs work as patient advocates for the care and recovery of the sick as well as } \\
\text { for the maintenance of their health. In their work as advocates for the patient, RNs use the } \\
\text { nursing process to assess, plan, implement, and evaluate nursing care of the sick and injured. } \\
\text { RNs have a significantly expanded scope of practice, education, and clinical training compared } \\
\text { with that of licensed practical nurses. }\end{array}$ \\
\hline RN jobs & $\begin{array}{l}\text { A worker who can be classified as a full-time or part-time RN. This is the fundamental unit of } \\
\text { measure used to estimate RN populations and is counted through a survey conducted by the } \\
\text { BLS every } 3 \text { years. }\end{array}$ \\
\hline RN demand & The estimated number of RN jobs needed to meet population needs. \\
\hline RN demand ratio & The number of RN jobs needed per 100000 people. \\
\hline RN shortage & The difference between a region's demand for RN jobs and that region's supply of RN jobs. \\
\hline RN shortage ratio & RN shortage per 100000 people. \\
\hline RN supply & The estimated number of $\mathrm{RN}$ jobs. \\
\hline RN supply ratio & The number of RN jobs per 100000 people. \\
\hline US Census Bureau (USCB) & $\begin{array}{l}\text { USCB is the government agency that is responsible for the US Census. USCB is responsible for } \\
\text { collecting and providing relevant data about the people and economy of the United States. }\end{array}$ \\
\hline
\end{tabular}

forecast models were created for both demand and supply of RN jobs. A grading methodology developed in previous studies ${ }^{14-16}$ was used to compare state shortage ratios between 2009 and 2030. States were further aggregated into larger regions to examine the national trends that contribute to statewide shortages.

\section{Demand Model}

Each state's demand for RN jobs was based on a methodology similar to that employed in the California
Regional Registered Nurse Workforce Forecast. ${ }^{15}$ We determined the projected personal heath expenditure (PHE) for each of the 50 states using the Centers for Medicare and Medicaid Services (CMS) published agebased PHE estimates ${ }^{17}$ and the US Census Bureau's (USCB) projected estimates of state age and population sizes. ${ }^{18}$ Using a univariate linear regression analysis, the national, historic Bureau of Labor Statistics (BLS)-reported RN jobs was regressed on national PHE values (STATA 8.2; Stata Corp, College Station, TX) for all available years (ie, 2000, 2004-2009), generating a correlation coefficient of 
$2.69 \times 10-^{6}$ with a standard error (SE) of $1.62 \times 10-^{7}\left(R^{2}=\right.$ $0.982,95 \%$ confidence interval $[\mathrm{CI}]=2.28 \times 10-^{6}$, $\left.3.11 \times 10-^{6} ; P<.001\right)$. This coefficient was used to convert change in PHE to change in RN jobs for the nation and each state. The national RN estimates were used to convert PHE changes in the 50 states, rather than each state's own correlation, to eliminate additional variables such as state economic responsiveness to increased health spending. The baseline for this model was the number of RN jobs necessary to maintain the current national RN ratio of 844 in 2009 (see Measures section for details). Projected increases in the number of RN jobs needed were added to this initial 2009 number in subsequent years to forecast future demand for RN jobs. The model's equations are given below:

$$
\begin{aligned}
\mathrm{D}_{\mathrm{R}, 2010} & =844 \times[2009 \text { Projected State Population }] / 10^{5} \\
& +2.69 \times 10^{-6} \times \Delta \mathrm{PHE}_{\mathrm{R}, 2009,2010}
\end{aligned}
$$

$$
\begin{aligned}
\mathrm{D}_{\mathrm{R}, 2011}= & 844 \times[2009 \text { Projected State Population }] / 10^{5} \\
& +2.69 \times 10^{-6} \times\left(\Delta \mathrm{PHE}_{\mathrm{R}, 2009,2010}+\Delta \mathrm{PHE}_{\mathrm{R}, 2010,2011}\right)
\end{aligned}
$$

$$
\begin{aligned}
\mathrm{D}_{\mathrm{R}, \mathrm{N}} & =844 \times[2009 \text { Projected State Population }] / 10^{5}+2.69 \times 10^{-6} \\
& \times \sum_{R}\left(\Delta \mathrm{PHE}_{2009,2010}+\Delta \mathrm{PHE}_{2010,2011}+\cdots+\Delta \mathrm{PHE}_{\mathrm{N}-1, \mathrm{~N}}\right)
\end{aligned}
$$

where $\mathrm{D}_{\mathrm{R}, \mathrm{N}}: \mathrm{D}=$ Demand, $\mathrm{R}=$ Region or State, $\mathrm{N}=$ Year; $\Delta \mathrm{PHE}_{\mathrm{N}-1, \mathrm{~N}}=\mathrm{PHE}_{\mathrm{N}}-\mathrm{PHE}_{\mathrm{N}-1} ; 844$ is the 2009 national mean of RN jobs; $2.69 \times 10^{-6}$ is the PHE correlation coefficient.

\section{Supply Model}

The supply model was developed under the assumption that current RN utilization, the education of new RNs, and, most important, the propensity for individuals to choose a career in nursing would remain constant. The propensity of a US individual to work as a nurse was calculated using the $\mathrm{RN}$ age population estimates produced by the Current Population Survey (CPS). ${ }^{19}$ Population estimates for years 2000 to 2009 were obtained from the CPS in the following 7 age categories: 16 to 19 years, 20 to 24 years, 25 to 34 years, 35 to 44 years, 45 to 54 years, 55 to 64 years, and 65 years and older. These estimates were divided by USCB population estimates in the same 7 age categories for 2000 to 2009, yielding propensities for an individual in the United States to choose to work as an RN at a given age. ${ }^{20}$ A 10 -year average was calculated for each age category and multiplied by state yearly population changes in each age category. ${ }^{18}$ Totaling this product in the 7 age categories yielded each state's projected changes through 2030. These changes were added to BLS-reported $2009 \mathrm{RN}$ job numbers. ${ }^{21}$ The formulas below contain supply model details:

$$
\begin{aligned}
\mathrm{S}_{\mathrm{R}, 2010} & =\mathrm{BLS}_{2009}+\sum_{\mathrm{R}}\left(\mathrm{P}_{\mathrm{A}} \times\left(\Delta \mathrm{POP}_{\mathrm{A}, 2009,2010}\right)\right) \\
\mathrm{S}_{\mathrm{R}, \mathrm{N}} & =\mathrm{BLS}_{2009}+\sum_{\mathrm{R}}\left(\mathrm{P}_{\mathrm{A}} \times\left(\Delta \mathrm{POP}_{\mathrm{A}, 2009,2010}\right)\right) \\
& +\sum_{R}\left(\mathrm{P}_{\mathrm{A}} \times\left(\Delta \mathrm{POP}_{\mathrm{A}, 2010,2011}\right)\right) \\
& +\cdots+\sum_{\mathrm{R}}\left(\mathrm{P}_{\mathrm{A}} \times\left(\Delta \mathrm{POP}_{\mathrm{A}, \mathrm{N}-1, \mathrm{~N}}\right)\right)
\end{aligned}
$$

where $S_{R, N}: S=$ Supply, $R=$ Region or State, $N=$ Year; $\mathrm{P}_{\mathrm{A}}: \mathrm{P}=$ Propensity averaged over 10 years, $\mathrm{A}=$ Age group; $\triangle \mathrm{POP}{ }_{\mathrm{A}, \mathrm{N}-1, \mathrm{~N}}=$ Age-category specific Population ${ }_{\mathrm{n}}-$ Population $_{\mathrm{N}-1}, \mathrm{BLS}_{2009}=$ the number of RN jobs reported by the BLS in 2009 .

\section{Measures}

The metric used for grading in this article is the RN shortage ratio, which is defined as the difference between demand and supply of RN jobs per 100000 people as demonstrated below:

$\frac{[\text { State }] \text { RN Demand }-[\text { State }] \text { RN Supply }}{[\text { State }] \text { Total Population }} \times 10^{5}=[$ State $]$ RN Shortage Ratio

The number of RN jobs was retrieved from the BLS. ${ }^{21}$ State populations were obtained from the Interim State Population Projections of the USCB. ${ }^{18}$ The 2009 report card was based on the national mean (844 RNs per 100 $000)$ and the standard deviation (SD) among the state RN ratios (163 RNs per 100 000). The 2009 national mean was used as a representative of the status quo for state performance in subsequent years. Note that this value differs from the national mean reported by the National Sample Survey of Registered Nurses, ${ }^{11}$ because of the use of a different USCB population estimate. USCB projection estimates ${ }^{18}$ were used to facilitate comparison with 2030 workforce projections rather than their annual population estimates. ${ }^{20}$ Letter grades in 2009 were assigned based on the difference between the national mean and each state's ratio, using the SD as the framework of the grading rubric. A and $\mathrm{F}$ grades were $\pm 2 \mathrm{SD}, \mathrm{B}$ and $\mathrm{D}$ grades were $\pm 1 \mathrm{SD}$, and $\mathrm{C}+$ and $\mathrm{C}$ - grades were $\pm 0.5 \mathrm{SD}$.

\section{Analytic Strategy}

Shortages for each state were determined as the difference between the projected $\mathrm{RN}$ demand and the projected 
$\mathrm{RN}$ job supply. This value was then converted to an $\mathrm{RN}$ shortage ratio by dividing the state $\mathrm{RN}$ job shortage by the state's projected population as forecasted by the USCB ${ }^{18}$ Using the 2009 shortage grading rubric described, grades were assigned to shortage ratios for 50 states in 2030. Using the proportion of full-time equivalent (FTE) employees to RNs providing nursing services estimated in the Health Resources and Services Administration's (HRSA) RN projection model, ${ }^{12}$ which averages 0.84 , a crude estimate of RN FTEs may be calculated for each state.

Upper and lower estimates for demand and supply were estimated using the $\mathrm{SE}$ of the demand regression slope as well as the SE of the 10-year supply mean propensity values. Shortage ranges were generated by calculating the difference between lower demand estimates and upper supply estimates (shortage range lower limit) and the difference between upper demand estimates and lower supply estimates (shortage range upper limit) of the $95 \%$ CI of both demand and supply models.

Performances of US regions also were analyzed. States were organized into 4 geographic regions defined by the BLS: the Midwest, the Northeast, the South, and the West (Table 2). ${ }^{22}$ Totaling the projected demand and supply values of each region and dividing by their states' forecasted populations yielded shortage ratios for each region, to which grades were then assigned.

\section{Results}

According to our forecasts, $\mathrm{RN}$ shortages will grow across the country between 2009 and 2030 (Table 2). In 2030, states with the largest shortages (ie, the largest number of RN jobs) will be California (193 100 jobs), Florida (128 364 jobs), and Texas (109 779 jobs); states with the largest shortage ratios (RN shortage per 100000 people) will be New Mexico (614), Arizona (530), and Nevada (453). Each state shows an increase in RN shortage ratio, ranging from 145 to 403 . States with the largest increase in shortage ratios are Florida (403), New Mexico (397), and Wyoming (387). With regard to grades, in 2009 there were $2 \mathrm{As}, 10 \mathrm{Bs}, 10 \mathrm{C}+\mathrm{s}, 17 \mathrm{Cs}, 6$ $\mathrm{C}-\mathrm{s}, 5 \mathrm{Ds}$, and zero Fs. In 2030, there will be zero As, 1 $\mathrm{B}, 1 \mathrm{C}+, 9 \mathrm{Cs}, 9 \mathrm{C}-\mathrm{s}, 18 \mathrm{Ds}$, and $12 \mathrm{Fs}$. Using a numeric grading scale with $\mathrm{A}=4, \mathrm{~B}=3, \mathrm{C}+=2.33, \mathrm{C}=2, \mathrm{C}-=$ $1.67, \mathrm{D}=1$, and $\mathrm{F}=0$, the average national grade is 2.21 in 2009 and 1.13 in 2030.

Among the 4 BLS-defined regions, those with the largest shortage in 2030 will be the South (420 691 jobs) and the West (358 637 jobs). The Midwest and Northeast will have lower shortages of 76170 and 68133 jobs, respectively. In terms of $\mathrm{RN}$ shortage ratios in 2030, the West is forecasted to have the greatest shortage (389 RN jobs per 100 000), followed by the South with 295 RN jobs per 100 000; the Midwest and the Northeast will have shortage ratios of 108 and 118 RNs per 100000 , respectively. All regions' letter grades fall by 2030; the Northeast and the Midwest decline from grade C+ (2009) to grade C- (2030), the South declines from C in 2009 to $\mathrm{D}$ in 2030, and the West declines from D to F. The South is expected to have the largest change in shortage ratio between 2009 and 2030, increasing by 271 . The Northeast has the next highest shortage ratio increase of 235 , followed by the Midwest and the West with shortage ratios for both increasing by $221 \mathrm{RN}$ jobs per 100000 .

\section{Discussion}

The forecasts in this study suggest that shortages of RNs will worsen in the next 2 decades. Among all 50 states, only 2 (Massachusetts and South Dakota) show an RN surplus in 2030, whereas 12 states, all in the South and the West, receive an $\mathrm{F}$ grade. The states with the most alarming condition are those with the largest changes in shortage ratio between 2009 and 2030 (Table 2). Florida will have the greatest increase in $\mathrm{RN}$ shortage ratio, rising $403 \mathrm{RN}$ jobs per 100000 by 2030 . This change likely is because of its high demand ratio growth at $36.3 \%$, representing the fastest growing demand of any state. Coupled with a supply that decreases $12.1 \%$ by 2030 , Florida has the fifth highest shortage ratio of 447 , and its shortage grade drops from $\mathrm{C}$ to $\mathrm{F}$ in 2030.

Many factors affect demand ratio. Among them, mean age is the most significant. Unlike population growth, which somewhat negates its impact by increasing both demand and supply populations, a rise in mean age serves to increase demand and decrease supply, causing shortage to grow. Thus, it is not surprising that states with larger changes in mean age show greater $\mathrm{RN}$ shortages. Exemplary of this pattern are New Mexico and Wyoming, states with the second and third highest demand ratio increases, which have the top 2 increases in mean age at 5.62 and 5.93 years between 2009 and 2030 (BLS reports an " $85+$ " category that we assume to be equal to 85 for mean age calculation). ${ }^{18}$

Age is the most significant factor in the shortage model presented in this article, not merely because of the magnitude by which a region's average age shifts but more specifically related to the growth in the number of individuals age 65 and older. With regard to the demand model, CMS estimates steadily increase with age because health care expenditure become greater as people age. ${ }^{17}$ Conversely, with the supply model, propensity for nursing is greatest between ages 45 and 54, decreasing to its second lowest value in the group who are age 65 and older (Figure 1). If populations in the age 65 and older category were to dramatically increase, one would expect rapid shortage growth compelled jointly by increasing 
Table 2. States Organized by BLS-Defined Region ${ }^{22}$ and the Change in RN-Related Factors for 2009-2030

\begin{tabular}{|c|c|c|c|c|c|c|c|}
\hline State & $\begin{array}{c}\text { Change in } \\
\text { Shortage Ratio }^{a}\end{array}$ & $\begin{array}{l}\text { Change in } \\
\text { Mean Age }^{\mathrm{a}}\end{array}$ & $\begin{array}{l}\text { Percent Population } \\
\text { Growth }^{\mathrm{a}}\end{array}$ & $\begin{array}{l}2030 \text { Shortage } \\
\text { Ratio }\end{array}$ & $\begin{array}{l}2030 \text { RN Shortage } \text { (the }^{\text {Number of RN Jobs) }}\end{array}$ & $\begin{array}{l}2009 \\
\text { Grade }\end{array}$ & $\begin{array}{l}2030 \\
\text { Grade }\end{array}$ \\
\hline \multicolumn{8}{|l|}{ The Northeast } \\
\hline Connecticut & 248 & 2.61 & 3.49 & 88 & $3259(2190,4336)$ & $\mathrm{C}+$ & $\mathrm{C}_{-}$ \\
\hline Maine & 353 & 4.83 & 4.54 & 129 & $1824(1199,2454)$ & B & $\mathrm{C}-$ \\
\hline Massachusetts & 271 & 2.52 & 5.83 & -138 & $-9690(-11974,-7389)$ & A & $\mathrm{C}+$ \\
\hline New Hampshire & 316 & 3.13 & 20.06 & 188 & $3091(2111,4077)$ & $\mathrm{C}+$ & $\mathrm{D}$ \\
\hline New Jersey & 228 & 2.64 & 9.31 & 238 & $23358(19526,27216)$ & $\mathrm{C}$ & $\mathrm{D}$ \\
\hline New York & 213 & 2.57 & 0.32 & 204 & $39696(35546,43877)$ & C & $\mathrm{D}$ \\
\hline Pennsylvania & 222 & 2.54 & 1.69 & 32 & $4091(1217,6988)$ & B & C \\
\hline Rhode Island & 233 & 2.82 & 3.75 & 31 & $354(30,680)$ & $B$ & C \\
\hline Vermont & 334 & 3.97 & 9.82 & 302 & $2149(1795,2506)$ & C & $\mathrm{D}$ \\
\hline \multicolumn{8}{|l|}{ The Midwest } \\
\hline Illinois & 195 & 2.15 & 4.31 & 136 & $18240(14800,21706)$ & $\mathrm{C}$ & $\mathrm{C}_{-}$ \\
\hline Indiana & 199 & 1.77 & 6.99 & 134 & $9112(7 \mid 63,11074)$ & $\mathrm{C}$ & $\mathrm{C}-$ \\
\hline lowa & 222 & 3.18 & -1.63 & 42 & $1243(683,1807)$ & B & $\mathrm{C}$ \\
\hline Kansas & 228 & 2.63 & 5.18 & 130 & $3827(2952,4709)$ & $\mathrm{C}_{+}$ & $\mathrm{C}-$ \\
\hline Michigan & 211 & 2.91 & 2.95 & 241 & $25725(22806,28666)$ & $\mathrm{C}$ & $\mathrm{D}$ \\
\hline Minnesota & 271 & 2.40 & $|7.4|$ & 44 & $2750(-342,5862)$ & $B$ & $\mathrm{C}$ \\
\hline Missouri & 238 & 2.30 & 9.14 & 27 & $1757(-536,4065)$ & B & C \\
\hline Nebraska & 242 & 2.26 & 3.16 & 13 & $238(-212,692)$ & B & $C$ \\
\hline North Dakota & 273 & 3.92 & -4.72 & 134 & $811(708,9 \mid 4)$ & $\mathrm{C}_{+}$ & $\mathrm{C}_{-}$ \\
\hline Ohio & 207 & 2.57 & -0.08 & 31 & $3630(1401,5876)$ & B & $\mathrm{C}$ \\
\hline South Dakota & 288 & 3.21 & 2.13 & -211 & $-1692(-1918,-1464)$ & A & B \\
\hline Wisconsin & 267 & 3.27 & 8.03 & 171 & $10530(8111,12965)$ & $\mathrm{C}_{+}$ & $\mathrm{D}$ \\
\hline \multicolumn{8}{|l|}{ The South } \\
\hline Alabama & 260 & 2.87 & 6.36 & 168 & $8212(6478,9957)$ & $\mathrm{C}+$ & $\mathrm{D}$ \\
\hline Arkansas & 227 & 2.14 & 13.45 & 264 & $8545(7162,9938)$ & $\mathrm{C}$ & $\mathrm{D}$ \\
\hline Delaware & 385 & 4.02 & 15.72 & 61 & $616(12,1223)$ & $B$ & $\mathrm{C}$ \\
\hline Florida & 403 & 3.48 & 51.86 & 447 & $128364(98043,158$ 878) & $\mathrm{C}$ & $\mathrm{F}$ \\
\hline Georgia & 206 & 2.04 & 27.07 & 358 & $43075(35884,50311)$ & $C_{-}$ & $\mathrm{F}$ \\
\hline Kentucky & 246 & 2.60 & 7.27 & 71 & $3244(1665,4835)$ & B & $\mathrm{C}$ \\
\hline Louisiana & 230 & 2.98 & 4.44 & 213 & $10249(8765,11743)$ & C & $\mathrm{D}$ \\
\hline Maryland & 223 & 1.50 & 20.16 & 184 & $12894(9455,16355)$ & $C$ & $D$ \\
\hline Mississippi & 250 & 3.93 & 4.43 & 147 & $4551(3449,5661)$ & $\mathrm{C}_{+}$ & $\mathrm{C}_{-}$ \\
\hline North Carolina & 283 & 1.35 & 32.68 & 171 & $20851(12786,28967)$ & $\mathrm{C}+$ & $\mathrm{D}$ \\
\hline Oklahoma & 204 & 1.68 & 9.38 & 284 & II I $20(9840,12410)$ & $\mathrm{C}$ & $\mathrm{D}$ \\
\hline South Carolina & 319 & 3.39 & 16.85 & 301 & 15477 (12 489, 18484$)$ & C & $\mathrm{D}$ \\
\hline Tennessee & 278 & 1.66 & 19.47 & 119 & $8770(5006,12560)$ & $\mathrm{C}+$ & $\mathrm{C}_{-}$ \\
\hline Texas & 178 & 1.93 & 37.26 & 329 & $109779(86881,132819)$ & C- & $\mathrm{F}$ \\
\hline Virginia & 247 & 1.90 & 24.07 & 330 & $32464(26$ 695, 38 27I) & $C_{-}$ & $\mathrm{F}$ \\
\hline West Virginia & 249 & 4.06 & -5.94 & 144 & $2480(2231,2732)$ & $\mathrm{C}+$ & $\mathrm{C}_{-}$ \\
\hline \multicolumn{8}{|l|}{ The West } \\
\hline Alaska & 227 & 1.04 & 26.31 & 341 & $2961(2496,3430)$ & C- & $\mathrm{F}$ \\
\hline Arizona & 281 & 3.28 & 65.37 & 530 & $5678 \mid(45$ II6,68 519) & $\mathrm{D}$ & $\mathrm{F}$ \\
\hline California & 190 & 2.74 & 23.31 & 416 & $193100(165642,220734)$ & $\mathrm{D}$ & $\mathrm{F}$ \\
\hline Colorado & 244 & 1.44 & 20.95 & 217 & $12550(9639,15479)$ & $\mathrm{C}$ & $\mathrm{D}$ \\
\hline Hawaii & 279 & 2.73 & 10.27 & 451 & $6617(5974,7266)$ & $\mathrm{D}$ & $\mathrm{F}$ \\
\hline Idaho & 208 & 3.28 & 31.76 & 347 & $6830(5428,824 I)$ & $\mathrm{C}-$ & $\mathrm{F}$ \\
\hline Montana & 356 & 4.76 & 8.65 & 333 & $3479(2937,4025)$ & C & $\mathrm{F}$ \\
\hline Nevada & 223 & 2.37 & 63.40 & 453 & $19398(15066,23756)$ & $\mathrm{D}$ & $\mathrm{F}$ \\
\hline New Mexico & 397 & 5.62 & 6.79 & 614 & $12884($ (I 728, 14 048) & $\mathrm{D}$ & $\mathrm{F}$ \\
\hline Oregon & 210 & 1.63 & 28.91 & 234 & II 32 I (8359, I4 302) & $\mathrm{C}$ & $\mathrm{D}$ \\
\hline Utah & 145 & 2.05 & 36.20 & 299 & $10416(8182,12664)$ & $\mathrm{C}_{-}$ & $\mathrm{D}$ \\
\hline Washington & 234 & 1.93 & 33.32 & 239 & $20609(14692,26564)$ & $\mathrm{C}$ & $\mathrm{D}$ \\
\hline Wyoming & 387 & 5.93 & 1.01 & 323 & $1689(1457,1923)$ & $\mathrm{C}$ & $\mathrm{D}$ \\
\hline
\end{tabular}

Abbreviations: BLS, Bureau of Labor Statistics; RN, registered nurse.

${ }^{a}$ Change or growth between 2009 and 2030 values. This is calculated as the differences for shortage ratio and mean age, but as a percentage for population growth. bultiplying the projected number of RN jobs by 0.84 may yield a crude estimate of full-time employees. This proportion was estimated from Health Resources and Services Administration model projections. ${ }^{12}$ 


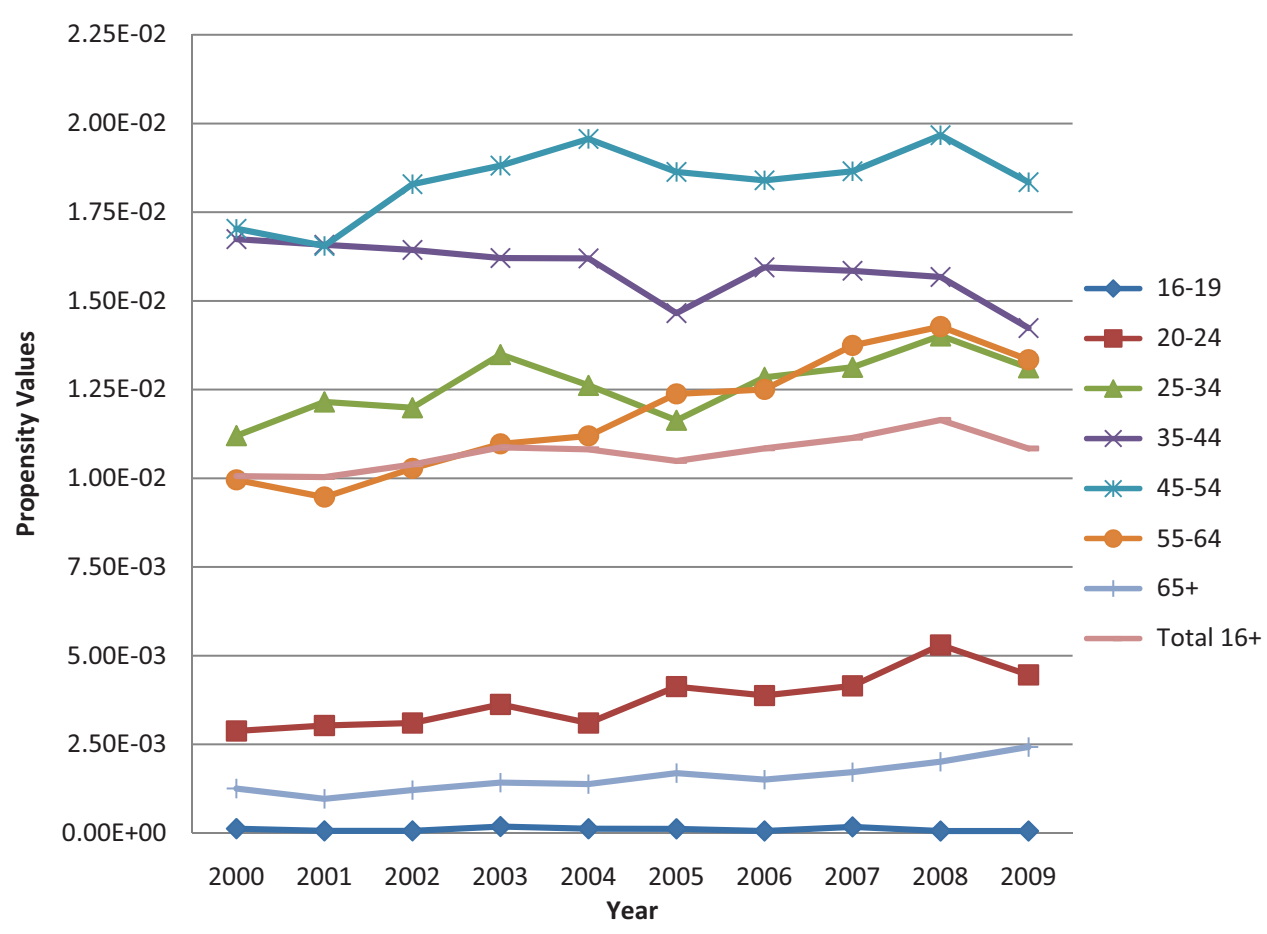

Figure I. Nursing propensity values from 2000 to 2009 stratified by age Abbreviation: $\mathrm{RN}$, registered nurse.

These values are based on the number of individuals estimated by the Current Population Survey to work as an RN in the Unites States divided by the US Census Bureau's population estimate for each respective year. ${ }^{19}$ Figure I demonstrates that those aged 45 to 54 years are the most likely to work as an RN. Furthermore, there has been a steady, gradual rise in the age 55 to 64 category over the past 10 years.

demand and decreasing supply, which unfortunately is the prognosis augured by US demographic forecasts concerning baby boomers.

Aging of the RN workforce is another factor contributing to future state shortages. According to the CPS, conducted by the USCB and the BLS, in 2003 those aged 45 to 54 years replaced those aged 35 to 44 years as the largest age group of RNs in the United States (Figure 2). ${ }^{19}$ This trend is reflected by the median RN age, reported to be 42.4 in 2000 and 45.4 in $2009 .{ }^{19}$ Some researchers project that the average age of RNs will continue to rise, not peaking until $2016 .{ }^{6}$ With about $50 \%$ of RNs within 20 years of retirement, ${ }^{19} \mathrm{RN}$ populations will require larger inflows to maintain historic linear increases in size. This change in $\mathrm{RN}$ demographics also is seen by variations in propensity values over the past 10 years. Between 1997 and 2009, the propensity for individuals aged 45 to 54 and 55 to 64 to hold an RN job has risen steadily (Figure 1). As baby boomers continue to work during their later years, it is possible that propensity values in the age 45 to 54,55 to 64 , and even the age 65 and older categories will continue to rise. However, the age 65 and older category has been fairly constant over the past 10 years, implying that there will be a high workforce attrition rate as the largest cohort of RNs advance beyond age 64 .

The recent economic recession as well as the health care reform law also will have an impact on the RN workforce. ${ }^{23,24}$ As the US economy recovers, economic pressure from the recent recession may force health care institutions to reduce their RN workforce, ${ }^{25,26}$ decreasing the number of jobs available to $\mathrm{RN}$ graduate ${ }^{27}$ and discouraging prospective nursing students in coming years. ${ }^{28}$ Meanwhile, by expanding coverage to 31 million uninsured Americans, ${ }^{29}$ health care reform legislation will increase demand for health services and for RN jobs. ${ }^{30}$ However, these laws also may limit compensation to health care providers and reduce $\mathrm{RN}$ salaries, ${ }^{31,32}$ which may affect the number of students interested in nursing as a career. Regardless of these recent changes in industry dynamics, a shortage of RNs will persist long term. ${ }^{33-35}$ With the retirement of aging baby boomers, who comprise $40 \%$ of the current health care workforce, there will be a dramatic reduction in $\mathrm{RN}$ supply. ${ }^{36}$

There are several limitations and assumptions inherent in our models that warrant discussion. In the demand model, one significant assumption is the use of the 2009 national mean as our starting point. This effectively causes 


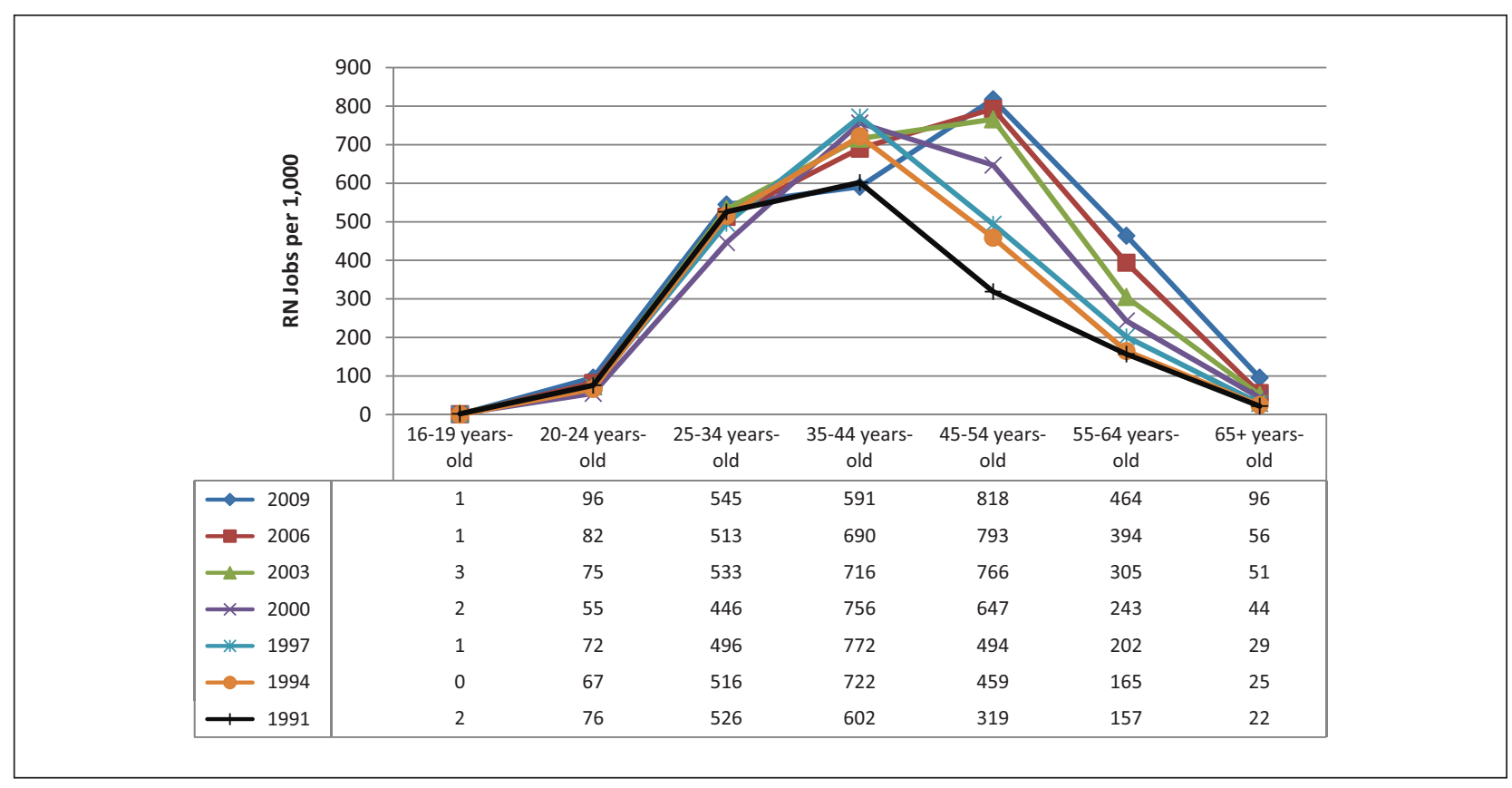

Figure 2. The number of RNs (thousands) within different age categories for selected years Abbreviation: RN, registered nurse.

Using Current Population Survey estimates of RN jobs by age category, ${ }^{19}$ this figure depicts trends in the nursing workforce over the past 20 years. Of note are the gradual increases in the number of RNs in the 45 to 54 and 55 to 64 age categories.

the nation to report no shortage in 2009, when most studies consider the nation to already experience a large shortage. Furthermore, in converting change in PHE to RN jobs, the national slope is used to avoid state variations in RN workforce responsiveness to health expenditures. Analysis of state correlations between RN jobs and PHE revealed that change in PHE translates to larger change in $\mathrm{RN}$ demand than represented by the national slope, which also would increase shortage projections substantially. Moreover, RN jobs are increased by health care expenditures, regardless of care setting. Although the majority of RNs work in hospitals, ambulatory care settings, and nursing homes or extended care facilities $\left(78 \%\right.$ in 2008), ${ }^{11}$ a large number are employed in a diverse range of environments including public health and government settings, nursing education, school health agencies, and pharmaceutical and insurance-related organizations. ${ }^{11} \mathrm{RN}$ jobs in these environments likely will be affected by the change in PHE to differing degrees. Another factor affecting this model is the use of 1999 PHE from CMS. There have been significant changes in the composition of PHE since 1999, including new technologies and the rising cost of medications, which may affect the relative cost between different age categories. ${ }^{17}$ Some speculate that the cost of providing health care to the elderly will decrease substantially in coming years, as chronic disability in the elderly is declining. ${ }^{37}$ This reduction in age-associated need for care could have an impact on future health care demand.
The supply model also has limitations. The primary assumption is that the national propensity of an individual to choose nursing as a career is the same across states in coming decades. This assumption does not address the range of socioeconomic factors that could influence career choices between different states or changes in the desirability of an RN career in coming years. Some models specifically ignore data older than 5 years, arguing that they are less pertinent and thus a poorer predictor of future $\mathrm{RN}$ labor dynamics. ${ }^{38}$ There is some indication as well that propensity values are changing over time, especially in the age 35 to 44 and 45 to 54 categories (Figure 2). Steady increases in these categories may increase future supply estimates. Other factors that would influence propensity values are changes in RN wages, US immigration policy, and technology development. As health care providers seek to fill vacancies, propensity values likely will change.

One additional limitation that affects our models is the projection of shortage in terms of $\mathrm{RN}$ jobs estimates rather than FTEs. FTEs are used frequently in projection models to depict the workforce contribution of full-time and parttime RNs. This requires survey data regarding the number of full-time and part-time RNs in each state and in the United States as a whole - data not gathered by the BLS in their attempt to estimate $\mathrm{RN}$ jobs. As a result, no direct conversion exists. A crude comparison may be made using projected HRSA RN FTEs and RN jobs $(\sim 0.84 \mathrm{FTEs} / \mathrm{RN}$ job) ${ }^{12}$; however, lack of this metric limits comparability to 
other models. Alternatively, this could represent a unique strength of our model, in that by estimating shortage in terms of RN jobs our projections are directly comparable with the estimates gathered by the BLS, the primary federal agency that tracks the RN labor market.

Other models that incorporate age and population change in national $\mathrm{RN}$ and general populations forebode trends similar to those found in our article. HRSA produced RN demand and supply models in $2002 .{ }^{12}$ In their demand model, population growth in 8 age categories was used to forecast health care utilization projections, whereas their supply model incorporated RN age as well as career attractiveness to youth. This model projected a workforce shortage of 1016900 FTE RNs in 2020. ${ }^{12}$ Auerbach et al used birth cohorts and RN age to determine the likelihood that individuals would choose to work as a nurse and, using HRSA's demand model, projected a shortage of 340000 FTE RNs in $2020 .{ }^{6}$ Unruh and Fottler defined demand as the number of FTE RNs required to serve future populations, with age and population growth being one of the primary factors considered. ${ }^{8}$ In their supply model, they relied on employment patterns of the RN population reported by the National Sample Survey of Registered Nurses, which involved RN age. As with other models, they projected a shortage increase, reported as a growth percentage, of $29 \%$ from 2000 to $2020 .^{8}$

One item universally agreed on by all models, ${ }^{6,8,12,13}$ regardless of assumptions or end-state projected values, is that the $\mathrm{RN}$ shortage is increasing steadily throughout the nation and will reach epic proportions in years when $\mathrm{RN}$ services are in highest demand. This shortage of RNs will influence the delivery of health care, negatively affecting patient outcomes. ${ }^{39,40}$ Policy makers and stakeholders are encouraged to move forward with the development of concrete national strategies to reduce shortages in regions of greatest need. Short-term strategies include more efficient use of the current RN workforce and retention of older $\mathrm{RNs}^{23}$ The nation is in great need of long-term solutions to maximize educational potential on a national level, as well as to improve $\mathrm{RN}$ working conditions to increase workforce participation rates. Future studies should examine economical means of using resources to effectively bolster the supply of RNs in those states with the greatest projected shortages.

\section{Acknowledgment}

The authors thank Paul Feldstein, PhD, Deloras Jones, RN, Ian Hsiao, $\mathrm{PhD}$, and Linda Bolton, RN, DrPH, FAAN, for their invaluable input into the production of this article.

\section{Declaration of Conflicting Interests}

The authors declared no potential conflicts of interest with respect to the research, authorship, and/or publication of this article.

\section{Funding}

The authors disclosed receipt of the following financial support for the research, authorship, and/or publication of this article: This study was supported in part by a grant from the California Institute for Nursing \& Health Care and the US Department of Veterans Affairs Rehabilitation Research and Development Service Merit Review Award. Mr Juraschek is funded by an NIH/NHLBI T32HL007024 Cardiovascular Epidemiology Training Grant.

\section{References}

1. Aiken LH, Clarke SP, Sloane DM, Sochalski J, Silber JH. Hospital nurse staffing and patient mortality, nurse burnout, and job dissatisfaction. JAMA. 2002;288: 1987-1993.

2. Blendon RJ, DesRoches CM, Brodie M, et al. Views of practicing physicians and the public on medical errors. N Engl J Med. 2002;347:1933-1940.

3. Clarke SP, Aiken LH. Failure to rescue. Am J Nurs. 2003;103: 42-47.

4. Needleman J, Buerhaus P, Mattke S, Stewart M, Zelevinsky K. Nurse-staffing levels and the quality of care in hospitals. $N$ Engl J Med. 2002;346:1715-1722.

5. Needleman J, Buerhaus PI, Stewart M, Zelevinsky K, Mattke S. Nurse staffing in hospitals: is there a business case for quality? Health Aff (Millwood). 2006;25: 204-211.

6. Auerbach DI, Buerhaus PI, Staiger DO. Better late than never: workforce supply implications of later entry into nursing. Health Aff (Millwood). 2007;26:178-185.

7. Hoover DR, Crystal S, Kumar R, Sambamoorthi U, Cantor JC. Medical expenditures during the last year of life: findings from the 1992-1996 Medicare current beneficiary survey. Health Serv Res. 2002;37:1625-1642.

8. Unruh LY, Fottler MD. Projections and trends in RN supply: what do they tell us about the nursing shortage? Policy Polit Nurs Pract. 2005;6:171-182.

9. Kovner CT, Mezey M, Harrington C. Who cares for older adults? Workforce implications of an aging society. Health Aff (Millwood). 2002;21:78-89.

10. National Center for Health Statistics. National Hospital Discharge Survey, 2004. http://www.cdc.gov/nchs/nhds. htm. Accessed November 28, 2010.

11. Health Resources and Services Administration. 2004 National Sample Survey of Registered Nurses. http://bhpr .hrsa.gov/healthworkforce/rnsurveys/rnsurvey2004.pdf. Accessed May 21, 2011.

12. Health Resources and Services Administration. Projected Supply, Demand, and Shortages of Registered Nurses: 2000-2020. Rockville, MD: National Center for Health Workforce Analysis; 2002.

13. Spetz J. Regional forecasts of the registered nurse workforce in California. http://futurehealth.ucsf.edu/Content/29/2006- 
08_Regional_Forecasts_of_the_Registered_Nurse_Workforce in_California.pdf. Published August 2006. Accessed May 21, 2011.

14. Lin VW, Lee A, Juraschek S, Jones D. California regional registered nurse workforce report card. Nurs Econ. 2006; 24:290-297, 279.

15. Lin VW, Juraschek SP, Xu L, Jones D, Turek J. California regional registered nurse workforce forecast. Nurs Econ. 2008;26:85-105, 121.

16. Zimbelman JL, Juraschek SP, Zhang X, Lin VW. Physical therapy workforce in the United States: forecasting nationwide shortages. PM R. 2010;2:1021-1029.

17. Keehan S, Lazenby H, Zezza M, Catlin A. Age estimates in the national health accounts. https://www.cms.gov/National HealthExpendData/downloads/keehan-age-estimates.pdf. Published December 2, 2004. Accessed May 21, 2011.

18. US Census Bureau, Population Division. Interim state population projections by single year of age: July 1, 2004 to 2030 . http://www.census.gov/population/www/projections/ projectionsagesex.html. Accessed August 1, 2010.

19. US Census Bureau and Bureau of Labor Statistics. The Current Population Survey: Table 15-Employed persons by detailed occupation, sex, and age, annual average, 20012010. Summary table at http://www.bls.gov/cps/tables. htm\#annual. Accessed May 21, 2011.

20. US Census Bureau. Annual estimates of the population for the United States, regions, states, and for Puerto Rico: April 1, 2000 to July 1, 2009. http:/www.census.gov/popest/states/ NST-ann-est.html. Accessed November 28, 2010.

21. Bureau of Labor Statistics. Healthcare practitioner and technical occupations profiles, 2010. http://www.bls.gov/oes/ current/oes_stru.htm\#29-0000. Accessed December 18, 2010.

22. Bureau of Labor Statistics. Region definitions. http://www .bls.gov/eag/home.htm. Accessed April 5, 2010.

23. Buerhaus PI, Auerbach DI, Staiger DO. The recent surge in nurse employment: causes and implications. Health Aff (Millwood).2009;28:w657-W668.

24. Rudel RJ, Moulton P, Arneson K. The shortage tsunami and high school guidance counselors' perspectives on future nurse recruitment. Medsurg Nurs. 2009;18:369374,384 .
25. Clark CS. The nursing shortage as a community transformational opportunity: an update. ANS Adv Nurs Sci. 2010;33:35-52.

26. Cline S. Can I afford to be healthy? N C Med J. 2009;70: 327-330.

27. American Association of Colleges of Nursing. Talking points: Impact of the economy on the nursing shortage http://www.aacn.nche.edu/Media/pdf/TalkingPoints.pdf. Accessed November 28, 2010.

28. Rosseter RJ. Nursing shortage fact sheet. http://www .aacn.nche.edu/media/pdf/NrsgShortageFS.pdf. Accessed November 28, 2010.

29. Yamey G. Obama's giant step towards universal health insurance. BMJ. 2010;340:c1674.

30. Markuns JF, Culpepper L, Halpin WJ Jr. Commentary: A need for leadership in primary health care for the underserved: a call to action. Acad Med. 2009;84:1325-1327.

31. Buerhaus PI. Health care payment reform: implications for nurses. Nurs Econ. 2010;28:49-54.

32. Sessions SY, Detsky AS. Employment and US health care reform: saving jobs while cutting costs. JAMA. 2009; 301:1811-1813.

33. Adams LT. Nursing shortage solutions and America's economic recovery. Nurs Educ Perspect. 2009;30:349.

34. Buerhaus $\mathrm{P}$. The recession and the nursing shortage. $O R$ Manager. 2009;25:5-6.

35. Carlson J. Nursing shortage eases . . . but only while the recession lasts, experts warn. Mod Healthc. 2009;39:8-9.

36. Buerhaus PI. Current and future state of the US nursing workforce. JAMA. 2008;300:2422-2424.

37. Manton KG. Recent declines in chronic disability in the elderly U.S. population: risk factors and future dynamics. Annu Rev Public Health. 2008;29:91-113.

38. Buerhaus PI, Staiger DO, Auerbach DI. Implications of an aging registered nurse workforce. JAMA. 2000;283: 2948-2954.

39. Charney W, Schirmer J. Nursing injury rates and negative patient outcomes - connecting the dots. AAOHN J. 2007; 55:470-475.

40. Zolnierek CD, Steckel CM. Negotiating safety when staffing falls short. Crit Care Nurs Clin North Am. 2010;22:261-269. 